\title{
Forts on Buton Island: Centres of settlement, government and security in Southeast Sulawesi
}

\author{
Hasanuddin
}

\section{Introduction}

From its establishment in the late sixteenth century, the Buton Sultanate, located at the southeast tip of Sulawesi (Figure 1.1 this volume), lay at the interface of the competing ambitions of the Makassar empire of southwest Sulawesi to the west and the Ternate empire of the northern Moluccas to the east (Andaya 1993). Geographically, the Buton Sultanate controlled a maritime area composed largely of multiple surrounding islands (Sarjiyanto 1999). Of these, Buton, Muna, Kabaena and Wawonii islands make up an archipelago. The Tukang Besi cluster of small islands to the southeast of Buton consists of Wangi-Wangi, Kaledupa, Hoga, Tomia and Binongko islands and their offshore islets. In addition, to the north of Muna lies Tiworo Island, surrounded by several groups of small islands, stretching in a chain from Siompu, Kadatua, Liwuto and Talaga islands to Rumbia and Poleang on the Southeast Sulawesi mainland. The straits between the islands are named the Buton Strait, Muna Strait and the Tiworo Straits respectively. For a map of the places referred to here, and the locations of the subdistricts with the forts referred to in this paper, see Sarjiyanto (1999:104).

The term Butonese covers the inhabitants of all former lands of the Buton Sultanate (Southon 1995) and extended to the southern portions of Southeast Sulawesi mainland. These lands reveal considerable diversity in cultural traditions and languages. Two main groups of languages can be distinguished, both belonging to the Western Malayo-Polynesian branch of Austronesian; those in the north of Buton Island, which belong to the Bungka-Mori group and are closely related to languages on the Southeast Sulawesi mainland; and those spoken elsewhere in the regency, which are classified in the Buton-Muna group (Bisht and Bankoti 2005:187).

Over 100 forts are associated with the Buton Sultanate (Sarjiyanto 1999). The best known of these is the imposing Buton Palace, located in the regency's capital city of Bau-Bau and completed in 1634 by the sixth Sultan of Buton, La Buke (Nur and Awat 2010). According to tradition, there were also a number of other important forts in operation earlier than, or contemporary with, the main fortified palace on Buton, including Fort Wabula, Fort Liwu, Fort Kombeli and Fort Takimpo, described in more detail below. 
This paper summarises the results of an archaeological survey of fortified settlements, and structures associated with the Buton Sultanate, in contemporary Southeast Sulawesi province. The research was undertaken by a team from the Makassar Branch of the Indonesian Archaeological Service. Field visits and site documentation were supplemented with interviews and discussions among local resident communities who sustain oral traditions and ceremonial associations with the sites.

\section{Geography and human ecology of Buton Regency}

Buton Regency is located within the Wallacean zoographical region and is rich in floral and faunal biodiversity, including coral reefs and tropical ecosystems. The region lies between latitude $4^{\circ} 25^{\prime}-5^{\circ} 45^{\prime} \mathrm{E}$ and longitude $120^{\circ} 30^{\prime}-123^{\circ} 30^{\prime} \mathrm{S}$ and is bounded by the Banda Sea to the east, the Flores Sea to the south, the Bone Gulf to the west and Muna regency to the north. The main crops include maize and tubers. Buton Island is rich in natural resources, including asphalt beds which have been mined and processed, as well as identified reserves of petroleum and gold (Wikipedia 2020).

Annual rainfall in Buton averages around $1904 \mathrm{~mm}$ with an average number of 109 wet days per year. The average temperature is approximately $27^{\circ} \mathrm{C}$, fluctuating between $21^{\circ} \mathrm{C}$ and $35^{\circ} \mathrm{C}$. From November to April, monsoon winds blow from west to east, carrying moisture and causing heavy rainfall. In the dry season, from May to October, the wind blows from east to west, carrying little moisture (Indonesia Tourism 2017).

The geology of Buton Island presented here is adapted from the 'Local historical manuscript' published by the Bau-Bau City Government Culture and Tourism Office (Anon. n.d.; see also Kandari et al. 2015). Buton Island, which was the centre of Buton Sultanate, consists of sedimentary rocks. Large rivers traverse the northern and central part of the island, although with little water during the dry season. The southern part of the island is rocky and largely barren. In general, the Buton Sultanate lands consisted of rocky plains and hills. Buton Regency is located on the migration path for large pelagic fish (tuna and skipjack) crossing between the Pacific Ocean and the Indian Ocean. As well as the prospects for offshore fishing, the open water surrounding Buton Island has long been used for coastal fisheries.

In addition to its marine wealth, the Buton Sultanate exploited its tropical forests for their abundance of products, such as rattan, resin and various types of high-quality timber, used for making medicines, home furniture and notably the 'Lambo' sailboats. Buton Regency also sits at the crossroads of trade and commerce between the east and west parts of the Indonesian archipelago. The combination of poor prospects for agriculture and strategically located expanses of sea led the people to choose a maritime life. ${ }^{1}$ Buton people sailed to all corners of the IndoMalaysian Archipelago, in boats that ranged in size from small craft accommodating a few people, to large vessels that could carry about 150 tons of goods. The Butonese became renowned as brave seamen and adroit merchants throughout the Indo-Malaysian Archipelago (Southon 1995).

\section{Theoretical orientation}

The long history of settlement on Buton has left a vital ancestral legacy of cherished customs and traditions. An example is the kande-kandea traditional feast still held in villages to pray for a sustainable and prosperous livelihood (Kumparan 2019). During this harvest festival, traditional dance and martial arts are performed and the elders give customary commandments

1 As testified by Coen in the early seventeenth century (Colenbrander 1919): 'Dit is een groot ende oock peupuleert landt, hebbende schoon hout daer- van men na wens ende begeerten vaertuych souden connen maken, als men maer volck brochte'. 
to young people based on the experiences of the ancestors. Another example is the traditional festivity formerly known as wapulaka performed in various villages (Bahari, Wabula, Bungi, Pasarwajo and Lasiimu). It serves as a discussion forum to address issues on social relations within the community and on access to natural resources protected by the stipulations of customary law (Baubau Post 2018).

The cooperative attitude that representatives of Buton society have to its traditions was witnessed firsthand by the research team from the Makassar Archaeology Office. To collect local information on Benteng Wabula, we initially aimed to interview informants in Wabula. In response to our request the community held a general meeting in the village hall attended by 32 people, including bearers of custom (pemangku adat), community leaders and the local authorities (the subdistrict head and Wabula village head). The meeting was designed to authorise a mainstream perception of the fort's historical and cultural background. The Buton cooperative attitude is built on the foundations of respect for the transcendent beings in the supernatural world. When several Wabula villagers escorted the team to Benteng Wabula, they asked permission of the tomb they believed to house the major ancestral figure of Wa Kaa Kaa, and 'reported' to her the aims and goals of the activities conducted by the Archaeology Office team. Similarly, the kande-kandea traditional feast involves prayers to transcendent ancestors performed as a voluntary pact to attain the communal goal of social identification and legitimation.

The cultural history of Buton can thus be viewed as its sociocultural symbol, which is the product of the sociocultural identity or 'local knowledge' of its people and remains important as a driving force in every walk of life (see Gosden 1994). However, while Buton's traditions are the receptacle of accumulated wisdom, they are susceptible to erosion by modern values. Buton's cultural history could quickly disappear if conflicting concepts inspired by modernity were allowed to confront it relentlessly. There is an urgent need to document Buton's cultural heritage before its traditions die out and are relegated to the status of myth.

This danger confronts the material culture in Buton, whose ruins and other physical remnants can still be observed, and which have contributed significantly to placing Buton's cultural history in a broader context. Unless Buton's built heritage is managed professionally and effectively, using a sociocultural approach customised to each region and recruiting the archaeological evidence to enrich the identification of Buton's sociocultural identity, its cultural significance will not be realised. The political importance during Buton's history of the four forts described here is the motivation for their study, including their implications for former settlement patterns and general community life (Hasanuddin 2010).

\section{Research methodology}

With the foregoing theoretical perspective, the questions to be explored in the research on Fort Wabula, Liwu, Kombeli and Takimpo are:

a. How was the fort architecture designed and constructed?

b. Besides being used as a fort, do the structures reveal evidence of residential compounds?

c. What were the cultural and historical conditions when the forts had a defensive function?

To address these questions, this research aims to:

a. Obtain data from archaeology, history and oral traditions to understand the buildings' structure.

b. Collect historical data from the literature and oral tradition to develop a historical periodisation for the forts and the roles they played. 
c. Research any building components contained within the forts.

d. Understand the cultural history of Buton society of relevance to the forts when they were in operation.

Research activities were carried out in two stages: first, by conducting a survey of surface archaeological data to record artefacts and traces of buildings; and second, conducting largely unstructured interviews with traditional community leaders familiar with the heritage of the structures in order to gain insights into the cultural history of the forts. All artefacts collected from the sites were classified and analysed in the context of their functional relation to building foundations, and the sociocultural significance of the archaeological materials according to local respondents.

\section{A short history of Buton}

The official language of the Buton Sultanate was a local language, Wolio, but Arabic was also used for preparing documents, and the Malay language (Bahasa Melayu) was also spoken throughout the territory. Etymologically, the name of Buton, according to local tradition, comes from Butu, a type of poisonous banyan (Barringtonia asiatica). The locals adopted this nickname as a marker from the archipelagic seafarers who often stopped for shelter in the island. When Islam came to Buton, there was an attempt to link the name with the Arabic language. It was said that the word Buton came from the Arabic word bathni or bathin, which means a stomach or womb (Rosdin 2014).

Prior to adopting Islam, the Buton Sultanate was the Buton kingdom, known as far away as Java by the time of the Majapahit empire. In his famous Sumpah Palapa oath, prime minister Gadjah Mada mentioned Buton. The existence of Buton as a country was recorded in the Desawarnana poem written by Mpu Prapanca in AD 1365 (Robson 1995). It was described as a village where the sages lived in a garden furnished with a giant phallus and water channels. The king was called Yang Mulia Mahaguru (the Honourable Grand Master).

Buton's early prominence is reflected in an oral tradition recorded by the Portuguese explorer Antonio Galvão when he visited the northern Moluccas in the late 1530s. According to this story, a prominent elder of the clove-producing island of Bacan ordered his men to cut some rattan but when they did this, blood gushed out and drew his attention to four serpent eggs hidden in the rocks. The elder guarded the eggs, which later hatched into the children of the king of Bacan, the king of the people of Papua, the king of Buton-Banggai and the woman who married the king of Loloda Island. These four were the ancestors of all the kings of these islands, reflecting a symbolic unity which underlies the continuing appeal of this tradition (Andaya 1993:53).

According to Buton's own oral tradition, Buton was established as a country by four people who came from the Malay Peninsula to Buton in the early thirteenth century AD. The four founding fathers, Sipanjonga, Simalui, Sitamanajo and Sijawangkati, are called the Mia Patamiana. Sipanjonga, Sijawangkati and their followers settled the Gundu-Gundu territory, while Simalui, Sitamanajo and their followers settled Parangkatopa. When Sipanjonga's group arrived at Buton (then called Kalampa), they raised their flag called longa-longa, the flag of the Malay kingdom. This became the official flag of the Buton kingdom. Simalui's group moved from place to place until they met the Sipanjonga group. The two groups then intermarried (Rosdin 2014).

Sipanjonga married Simalui's sister, Sibaana, and had a son named Betoambari. Betoambari later married Wasigirina, the daughter of King Kamaru, and had a son named Sangariarana. Betoambari became the ruler of Peropa, and Sangariarana ruled the Baluwu territory. This resulted in four villages tied in kinship, namely Gundu-Gundu, Barangkatopa, Peropa and Baluwu (Hasanuddin 2010).

\section{terra austiralis 53}


Later, the four villages formed a union called the Empat Limbo, with each village represented by its leader, who was titled Bonto. The four Bonto also appointed their leader, who was titled Patalimbona (Rosdin 2014). The Empat Limbo acted as the legislative body to appoint and crown a king, and also brought into the union other, smaller kingdoms that had started to emerge in Buton, such as Tobe-Tobe, Kamaru, Wabula, Todanga and Batauga. Thus the Buton kingdom was established with the appointment of Wa Kaa Kaa (a woman married to Si Batara, a descendant of Majapahit royalty) as 'Raja I' in 1332 (Hasanuddin 2010).

Wabula tradition has a slightly different account for the inauguration of the Wolio/Buton kingdom. A man named Rajawangkati founded the kingdom of Koncu. Wa Kaa Kaa, also known as Toweke, was interested in local political developments if she was allowed to be ruler. Rajawangkati willingly crowned Wa Kaa Kaa as the first 'Kolakino' of Koncu. They shared political power according to the following formula. The legislative power, the highest power, fell into the hands of Rajawangkati or his successors who were called namapusaka, or the natives. The executive or the legislative mandate fell into the hands of Wa Kaa Kaa and her successors, called the Anano Bangule. If the Anano Bangule could not meet the requirement of providing a ruling 'Kakolaki' (or 'Parabela'), the executive power was taken over by the namapusaka.

The Buton kingdom flourished during the reign of six rulers up to 1542. Two rulers, Bulawambona as well as Wa Kaa Kaa, were queens. The reign of these two queens shows that women were equal to men in Buton society at that time. Islam made its initial entry to Buton Island as early as 1412. The ulemma Sayid Jamaluddin was invited by Raja Mulae Sangia i-Gola who converted to Islam shortly after. Missionary activity was continued for over a century later, which ushered in Buton's Sultanate phase. According to the main account, the saint responsible was Syeikh Abdul Wahid bin Syarif Sulaiman al-Fathani, reputed to have come from Johore via Ternate. In addition to converting the populace of Callasusung (Kalensusu), a region within the Buton realm, he converted Buton's sixth king, Lakilaponto (also known as Timbang Timbangan or Halu Oleo), in 1542. Lakilaponto thus became the first sultan with the title Sultan Murhum Kaimuddin Khalifatul Khamis. The Sultanate phase ended with the 38th and last sultan, Muhammad Falihi Kaimuddin, whose reign ended in 1960 (Hasanuddin 2010).

The influence of Islam was considerable, especially in the elements of Sufism. The laws of Buton were called the Murtabat Tujuh ('Seven Grades'), a popular term in tasawwuf (the spiritual dimension of Islam). These laws regulated the duties, functions and positions of the Sultanate ministers. The judicative body was run strictly without discriminating between members of the royal family, the sultan's retainers and the subjects. This was evident in the enforcement of law in Buton. Out of 38 sultans reigning in Buton, 12 of them were punished for violating their oath of office. Among them was the eighth sultan, Mardan Ali, who was sentenced to death by tightening a rope around his neck until it snapped, a form of execution known as gogoli (Kompas 2010).

After Lakilaponto converted to Islam, the Buton Sultanate flourished and reached its golden age in the seventeenth century. Buton ruled all of Buton Island and some neighbouring islands but allowed for regional autonomy by recognising 72 kadie (small areas). Buton built a strong relationship with Luwu, Konawe and Muna in Sulawesi. In the economic sector, money as a medium of exchange was introduced, called kampua (made of cotton spun into thread and woven traditionally to make cloth). Taxation was initially collected from each rural district by an officer named the tunggu weti. However, following economic development the tunggu weti was elevated to the position of Bonto Ogena (high minister), and additional duties were added to his portfolio including finance and heading the Siolimbona-similar to the modern chairman of a legislative body (Purwanto 2016; Rosdin 2014). 
Buton was an island region set strategically in the sea-trade route connecting spice-producing islands in the east and the traders from the west of the archipelago. Because of its strategic location, Buton was vulnerable to external threats, both from pirates and from foreign kingdoms that wanted to conquer it. To ward off these threats, a multilayered defence system was established. The first layer consisted of four Baratas, namely Wuna, Tiworo, Kulisusu and Kaledupa, and the second layer consisted of four Matana Sorumba, namely Wabula, Lapandewa, Watumotobe and Mawasangka. The third layer, of spiritual defence, consisted of four people called the Bhisa Patamiana (Hasanuddin 2010).

\section{Forts in Buton}

To strengthen the multilayered defence system of the Buton Sultanate, forts and defence posts were built from the late sixteenth century. Forts are scattered across Buton's length and breadth, with its diverse language and customs. Examples include Fort Bonelaio on Siompu Island, Fort Lasalimu in Lasalimu village and Fort Ereke in North Buton (author's field notes). Chief among them is the Buton Palace, also known as Fort Wolio (Sarjiyanto 1999), a massive military defensive fortification overlooking Bau-Bau city, which stands magnificently even today (Nur and Awat 2010). It was located in an elevated position $3 \mathrm{~km}$ from the beach so that the plains and ocean around the Bau-Bau Gulf could be seen clearly from the fort. The outer brick wall was $2.74 \mathrm{~km}$ long, enclosing an area of over 4000 ha. The walls are 1-2 m thick and 2-8 $\mathrm{m}$ high, equipped with 16 bastions and 12 gates.

Four smaller forts (benteng) were surveyed on Buton Island as part of the author's research. Fort Koncu (or Fort Wabula) and Fort Liwu lie within a kilometre of each other in Desa Wabula (Wabula subdistrict) on the southeast coast of the island. Two other fort sites, Kombeli and Takimpo, lie within the Pasar Wajo subdistrict due east of Bau-Bau city. All of them are built from quarried blocks of naturally occurring coral limestone. Their geographical location and altitude above sea level are presented at Table 8.1.

Table 8.1. Geographical details of the four surveyed Buton forts.

\begin{tabular}{|l|l|l|l|l|}
\hline Fort & Latitude & Longitude & Altitude above sea level & Setting \\
\hline Koncu & $05^{\circ} 37^{\prime} 07.1^{\prime \prime} \mathrm{S}$ & $122^{\circ} 49^{\prime} 30.4^{\prime \prime} \mathrm{E}$ & $325 \mathrm{~m}$ & Limestone hilltop \\
\hline Liwu & $05^{\circ} 37^{\prime} 04.6^{\prime \prime} \mathrm{S}$ & $122^{\circ} 49^{\prime} 32.1^{\prime \prime} \mathrm{E}$ & $301 \mathrm{~m}$ & Limestone hilltop \\
\hline Kombeli & $05^{\circ} 32^{\prime} 41.9^{\prime \prime} \mathrm{S}$ & $122^{\circ} 49^{\prime} 13.1^{\prime \prime} \mathrm{E}$ & $150 \mathrm{~m}$ & Limestone hillside \\
\hline Takimp0 & $05^{\circ} 32^{\prime} 47.3^{\prime \prime} \mathrm{S}$ & $122^{\circ} 51^{\prime} 02.5^{\prime \prime} \mathrm{E}$ & $179 \mathrm{~m}$ & Limestone hilltop \\
\hline
\end{tabular}

Source: Author's summary.

\section{Fort Koncu (Fort Wabula)}

Fort Koncu features high plastered walls made of coral rocks. It contains an ancient tomb and is the site of the former grand meeting house called galampa in the local language. According to local tradition, this was the settlement of the first ruler of Koncu, Wa Kaa Kaa, and her closest kin. The walls were used as the border between Wa Kaa Kaa's living quarters and those of her guards. The fort can be categorised as a simple royal residential compound. There is no evidence of architectural elements of bastions, army barracks or logistics storage often found in the defensive forts of other parts of Indonesia, such as Somba Opu (Reid 1983:144-145) or Cenrana (Andaya 1981:Map 8) in South Sulawesi. Nor are there any traces of a town square abutting the palace, as found in Islamic cities in Indonesia such as Yogyakarta and Banten in Java and Palopo in South Sulawesi. 


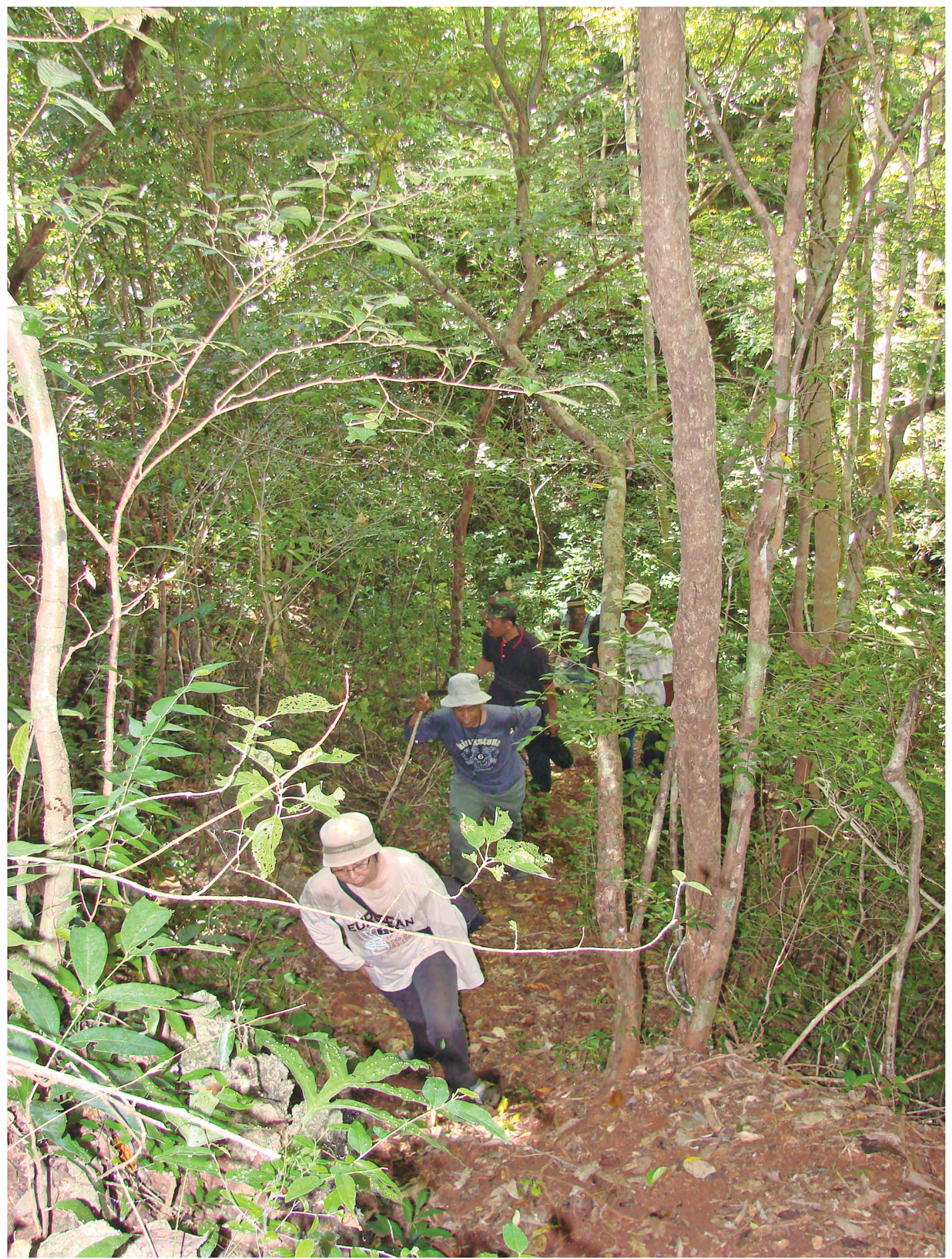

Figure 8.1. A steep section of the route to Fort Koncu.

Source: Photo courtesy of Hasanuddin.

Fort Koncu is also known as Kampung Bugi Lama or Kampung Wabula II (Figure 8.1) and access to the site involved a $75 \mathrm{~km}$ drive from Bau-Bau to Wasuemba (Wabula village), followed by a trek of 3 to 3.5 hours through woods along village footpaths. The footpath became steeper some $6 \mathrm{~km}$ from the village (Figure 8.1). 


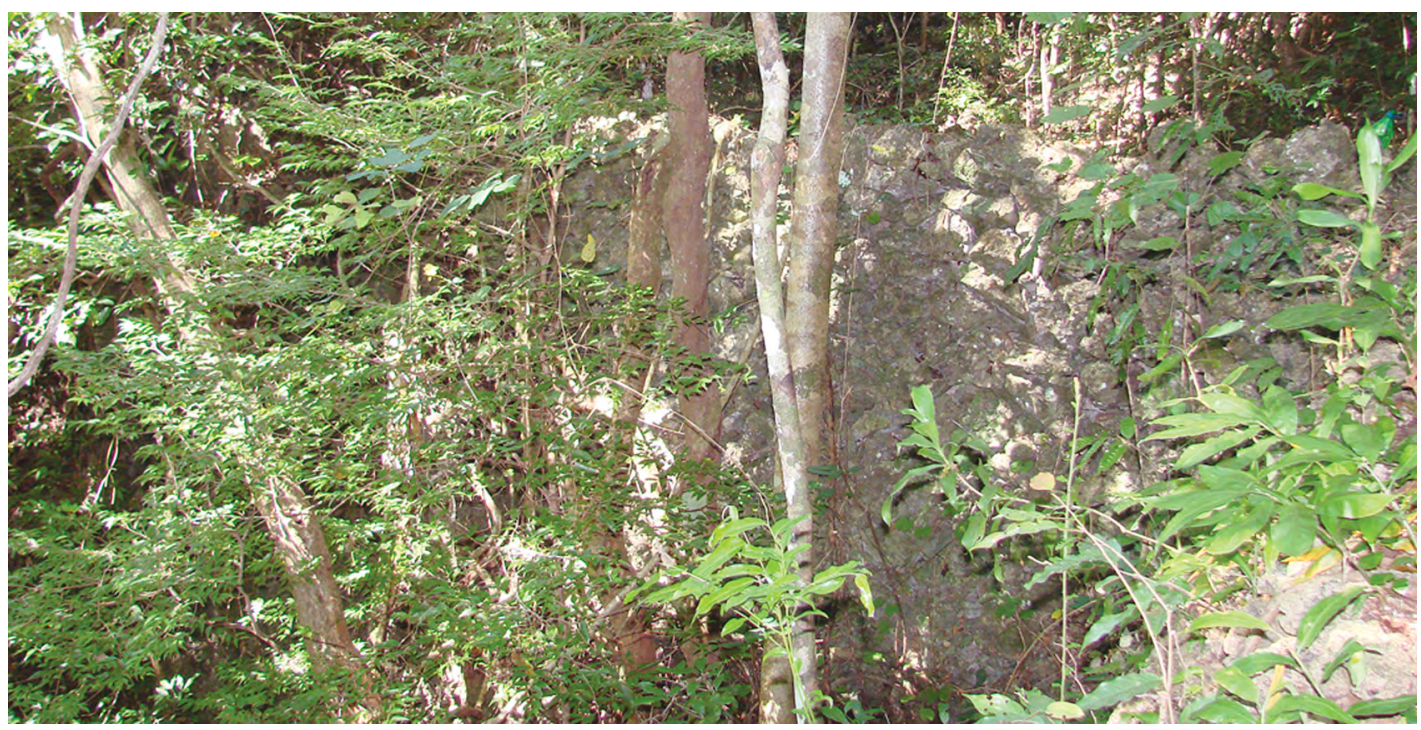

Figure 8.2. The remaining wall structure of Fort Koncu on the eastern side.

Source: Photo courtesy of Hasanuddin.

The walls of coral rock and limestone surrounding the compound (Figure 8.2) taper inwards vertically, from a thickness of about $310 \mathrm{~cm}$ at the base to $150-200 \mathrm{~cm}$ towards the top. The average height of the walls varies from 300 to $500 \mathrm{~cm}$, according to the contour of the land on which they were built. In the northern and southern parts, the walls curve to adjust to the contour of the land, so this opposing pair of walls is not symmetrical. Also, along part of the eastern perimeter, a steep $60 \mathrm{~m}$ cliff abuts the fort, and no rock structure was built here. There is only one entry gate (lawa in the local language) to the fort, located between the eastern and northern sides and referred to as Lawa Lakedo.

Apart from the walls, another visible structure at the site is a rectangular building with ceramic flooring and a zinc roof. This is believed to be the place where the first ruler, Wa Kaa Kaa, was buried (Figure 8.3). On its surface an oval block of limestone has been laid, festooned with offerings placed there by visitors to her gravesite on important days in the Islamic calendar (e.g. Bulan Suci Ramadan) to seek blessings at the site. The reconstruction of the gravesite follows the north-south orientation of Islamic graves in Indonesia, although there are no tombstones to mark the location of the head or feet, as is often found with Islamic graves.

The uneven ground surface found around the building is typical only of ancient tombs and so supports the belief that this was a royal burial site. However, it calls into question any claims that a former palace was located at the site. Surveys conducted at the location revealed the presence of sharp-pointed coral rocks, but nothing in the way of artefacts, such as earthenware or ceramic fragments, to indicate human settlement in the past.

Our informants took us to a nearby location, with a relatively flat surface on the west side of Fort Koncu, declaring it as the place where Wa Kaa Kaa's palace once stood. Here there was no sign of foundations or a cornerstone at the indicated location, just a small wooden building erected on one post by the local people as a memorial to the palace. The masted wooden building serves as a site for ritual activity and offerings. 


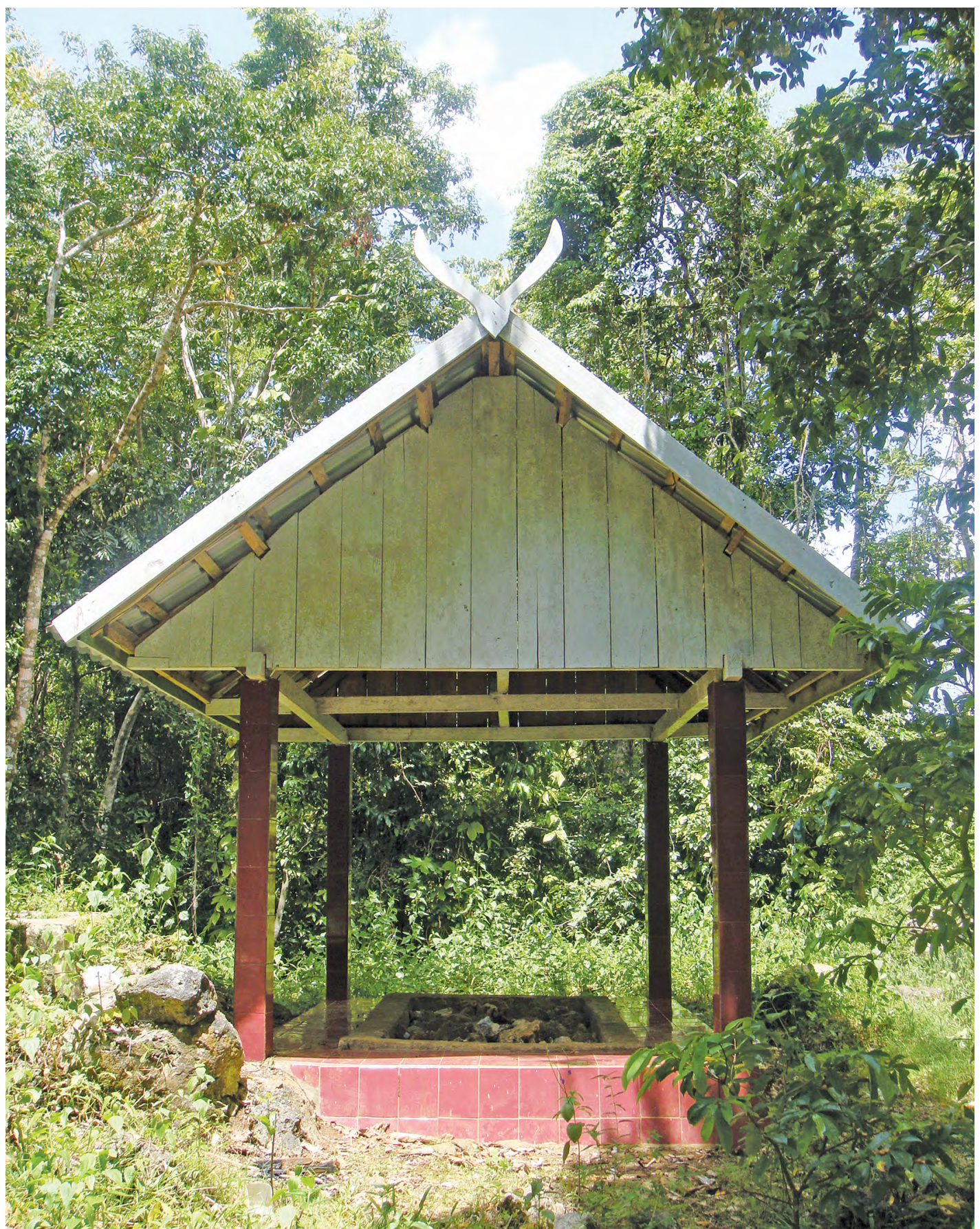

Figure 8.3. Wa Kaa Kaa's grave.

Source: Photo courtesy of Hasanuddin.

Inside Fort Koncu, natural stone features are placed adjacent to each other separated by a small passage through which visitors can enter the fort. According to the local people, this was the location of the royal agreement slab. The stone is engraved with etchings that are generally vertical and have an average length of $10 \mathrm{~cm}$ (Figure 8.4). According to our informants, wrongdoers who had violated the customary law were brought before this place for their verdict to be delivered. The most severe punishment was for the convicted offender to be bound and thrown into the sea alive, a punishment still practised during the pre-Islamic era, for instance in Tammejarra, Mandar, West Sulawesi and Jera Pallette, Bone, South Sulawesi. 


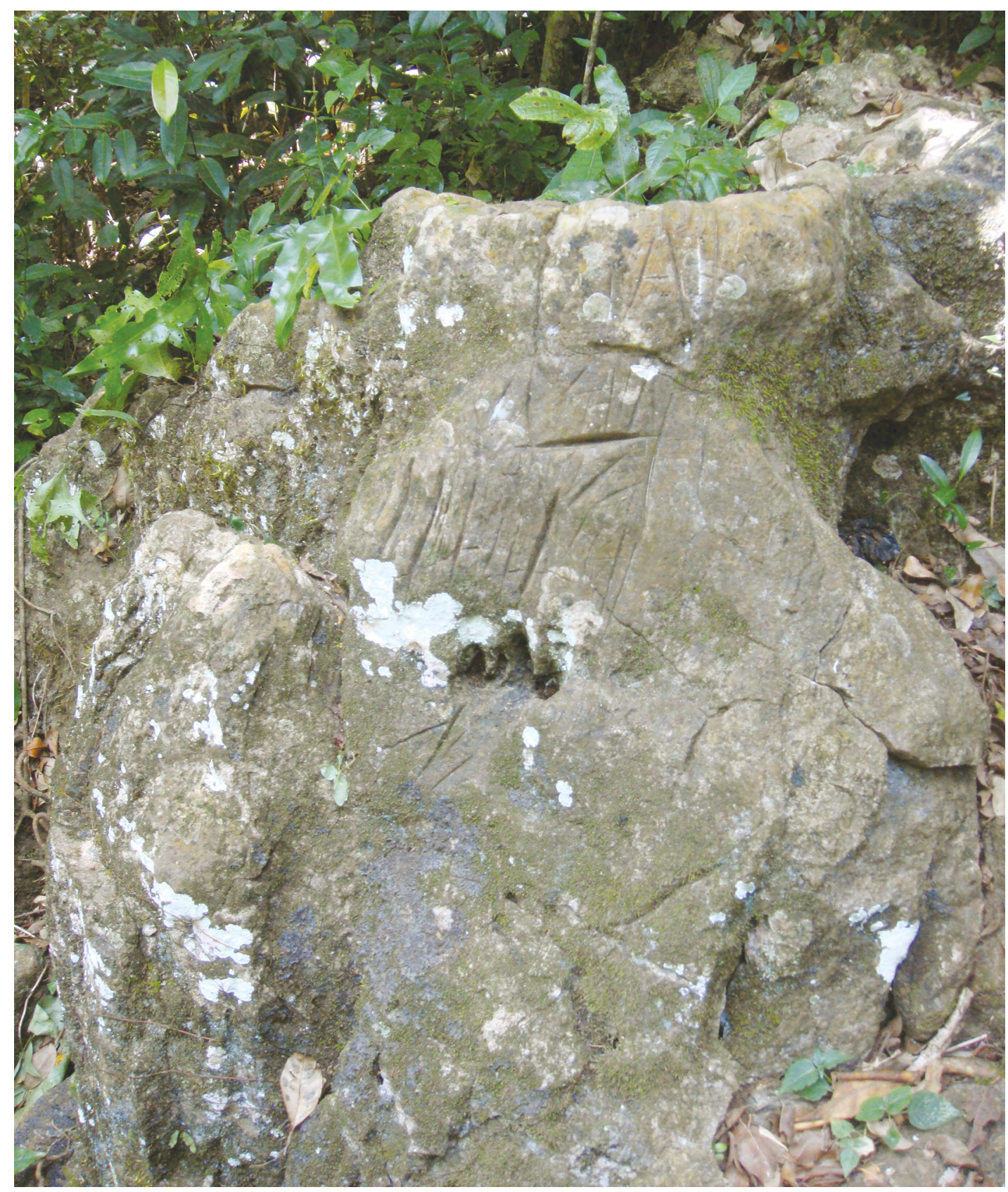

Figure 8.4. An etched rock said to have been the place of royal agreement.

Source: Photo courtesy of Hasanuddin.

The other main finding during the survey was a circular arrangement of limestone blocks with a rock in the middle bordering a $60 \mathrm{~cm}$ deep hole, located on the west side of Wa Kaa Kaa's grave (Figure 8.5). The circular stone structure evokes the temu gelang (meeting circle) commonly found at megalithic sites in Indonesia, especially Soppeng in South Sulawesi. In other areas, such as Bantaeng and Bulukumba in South Sulawesi, similar stone arrangements are thought to represent symbolically the centre of the world (Bugis = pocci tana, pocci Butta). Although our informants were unsure as how exactly to interpret this feature, it is likely to be a microcosmic representation of the human world - in view of its shape, its location within the sacred area at the top of a mountain, the reputation of Koncu as the oldest village in Wabula, and Wa Kaa Kaa's palace site. 


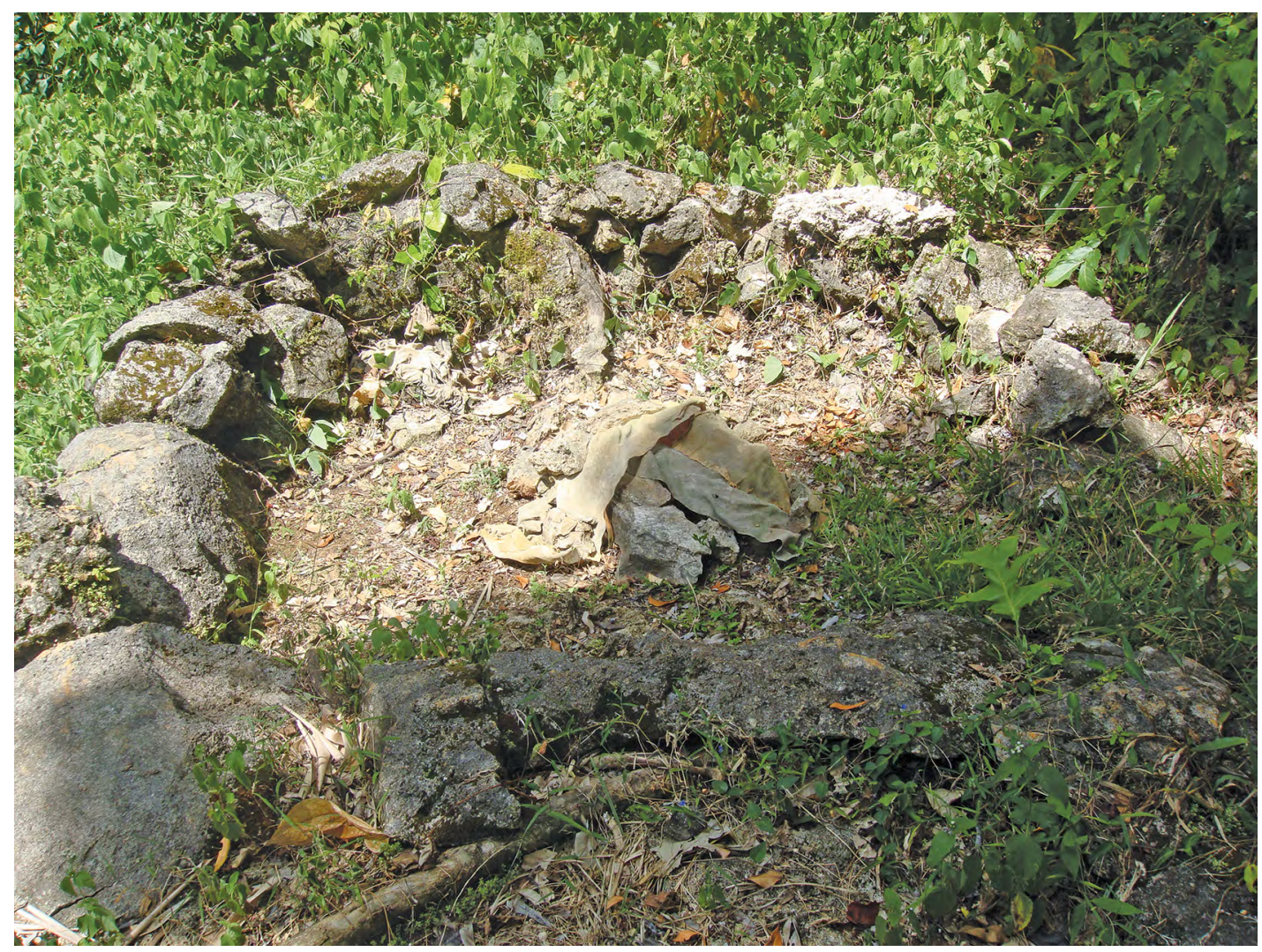

Figure 8.5. Limestone arrangement in the shape of a ring thought to symbolise the centre of the world. Source: Photo courtesy of Hasanuddin.

In addition, there is an upright limestone monolith that has not been used in building the walls. It was a place of ritual ceremonies for residents preparing to go to war, like the one found in the ancient Sengkae fort of the Siang kingdom of South Sulawesi (Fadillah and Mahmud 2000:28).

\section{Fort Liwu}

Early in Buton's history, the population evidently abandoned Fort Koncu and relocated to Liwu, an area about $1 \mathrm{~km}$ to the north. The likely causes were increasing population growth and the prospects to facilitate access and enhance relationships with outsiders. This is because Liwu's location is very strategic, making it ideal as a location for defensive settlement. From Liwu, activities in the neighbouring mountains and the Flores Sea can be monitored (Hasanuddin 2010).

Pedestrian travel from Fort Koncu to Fort Liwu was relatively easy. The track followed an undulating surface along the edge of the cliff to reach the east-west oriented limestone plateau crowned by the fort (Figure 8.6). To reach Fort Liwu from the Wasuemba coastal village, the track negotiates steep uphill pathways through the woods.

Fort Liwu was built of uncoursed, local coral rocks, like Fort Koncu, but it clearly functioned as a defensive fort. The walls were built in two sections, with the outer section higher than the inner. In addition, the fort has a rectangular shape with a bastion at each of its four corners (Figure 8.7). Each of the four sides has an entrance gate with a different name, namely lawa magasa for the north gate, lawa E'e for the east gate, lawa amagasa for the south gate, and lawa Wolio for the west gate. Three of the entrance gates can be accessed by land, but lawa E'e (the water gate) can only be accessed from the seaside. 


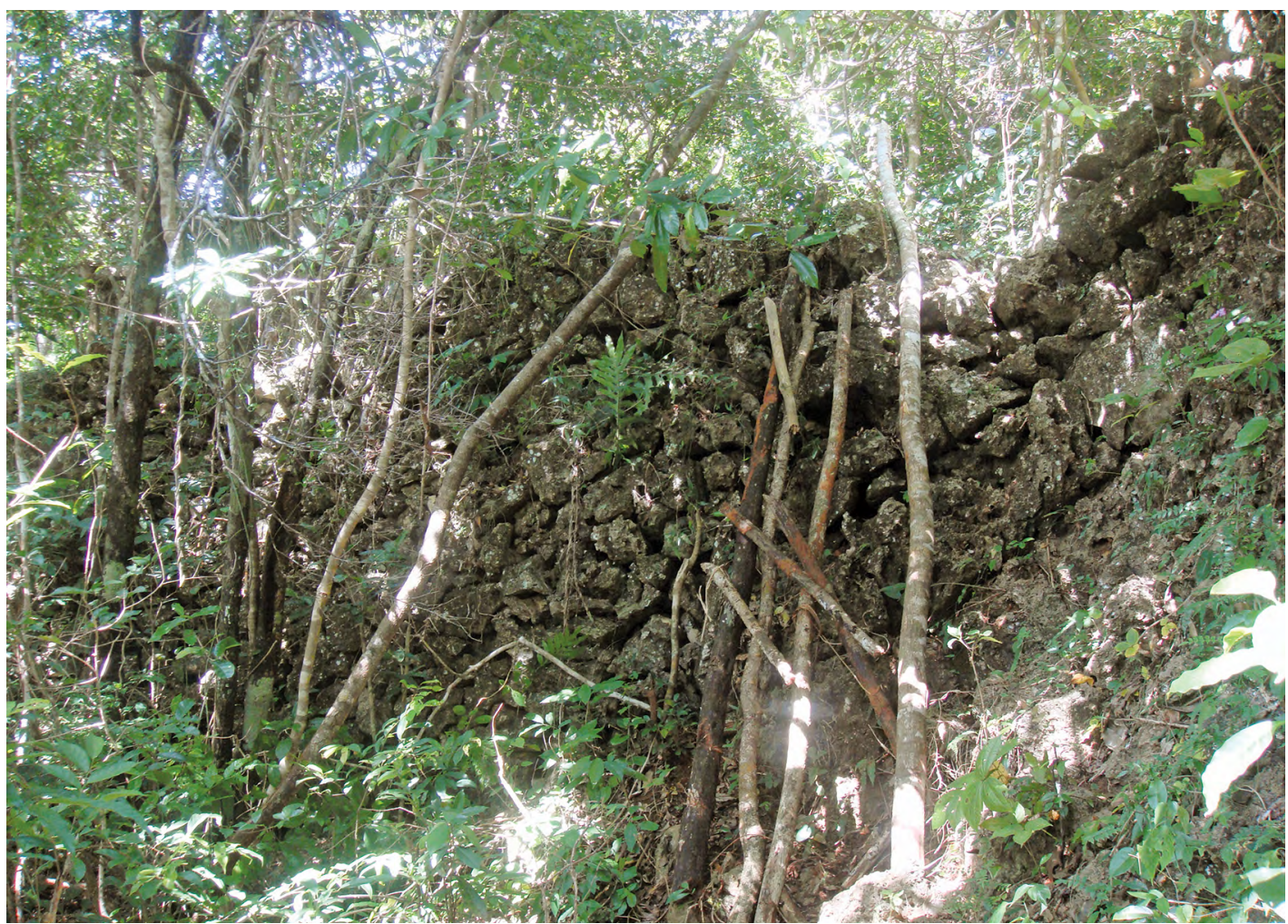

Figure 8.6. The ruins of the wall structure of Fort Liwu.

Source: Photo courtesy of Hasanuddin.

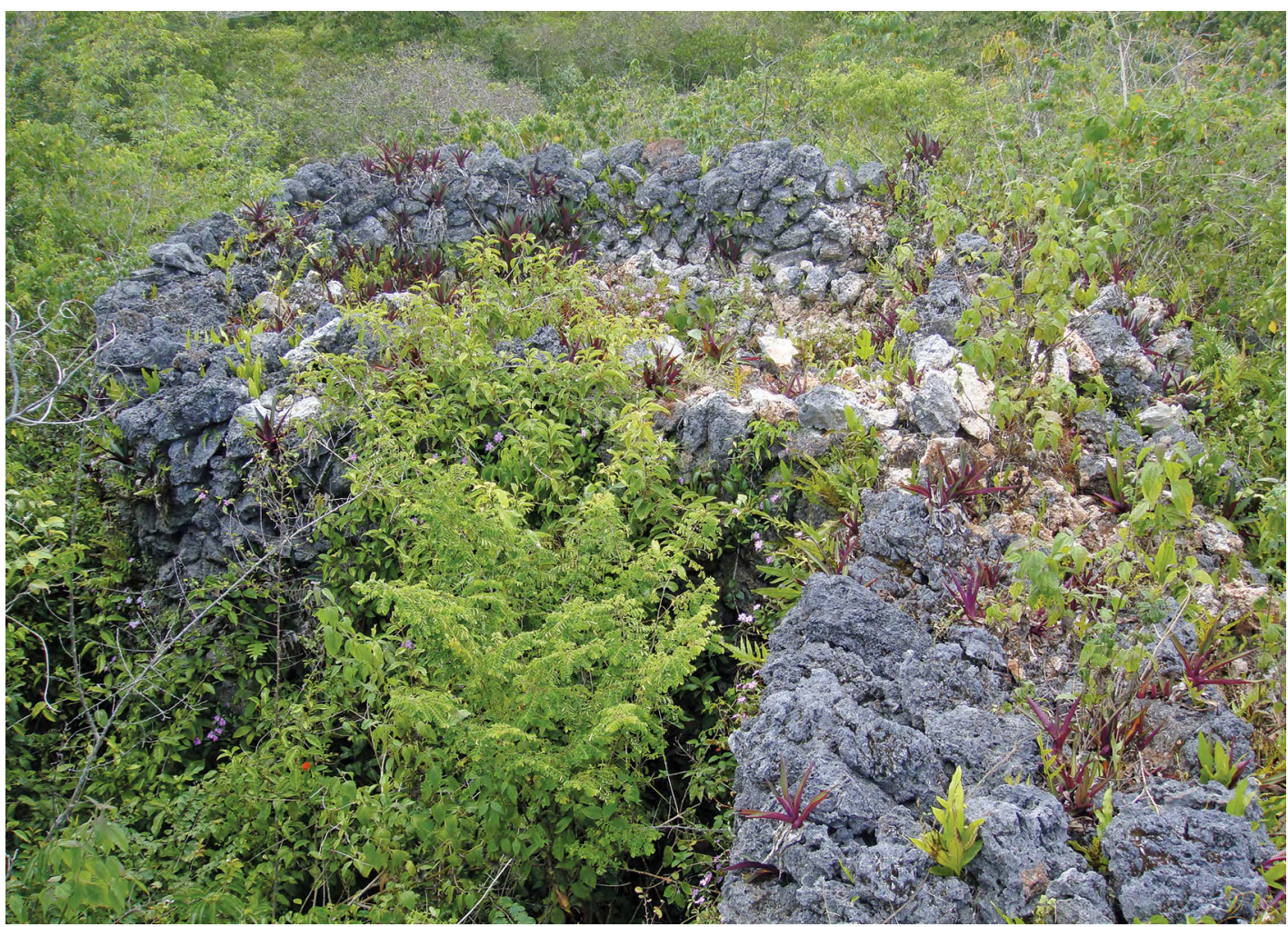

Figure 8.7. One of the corner bastions of Fort Liwu.

Source: Photo courtesy of Hasanuddin. 


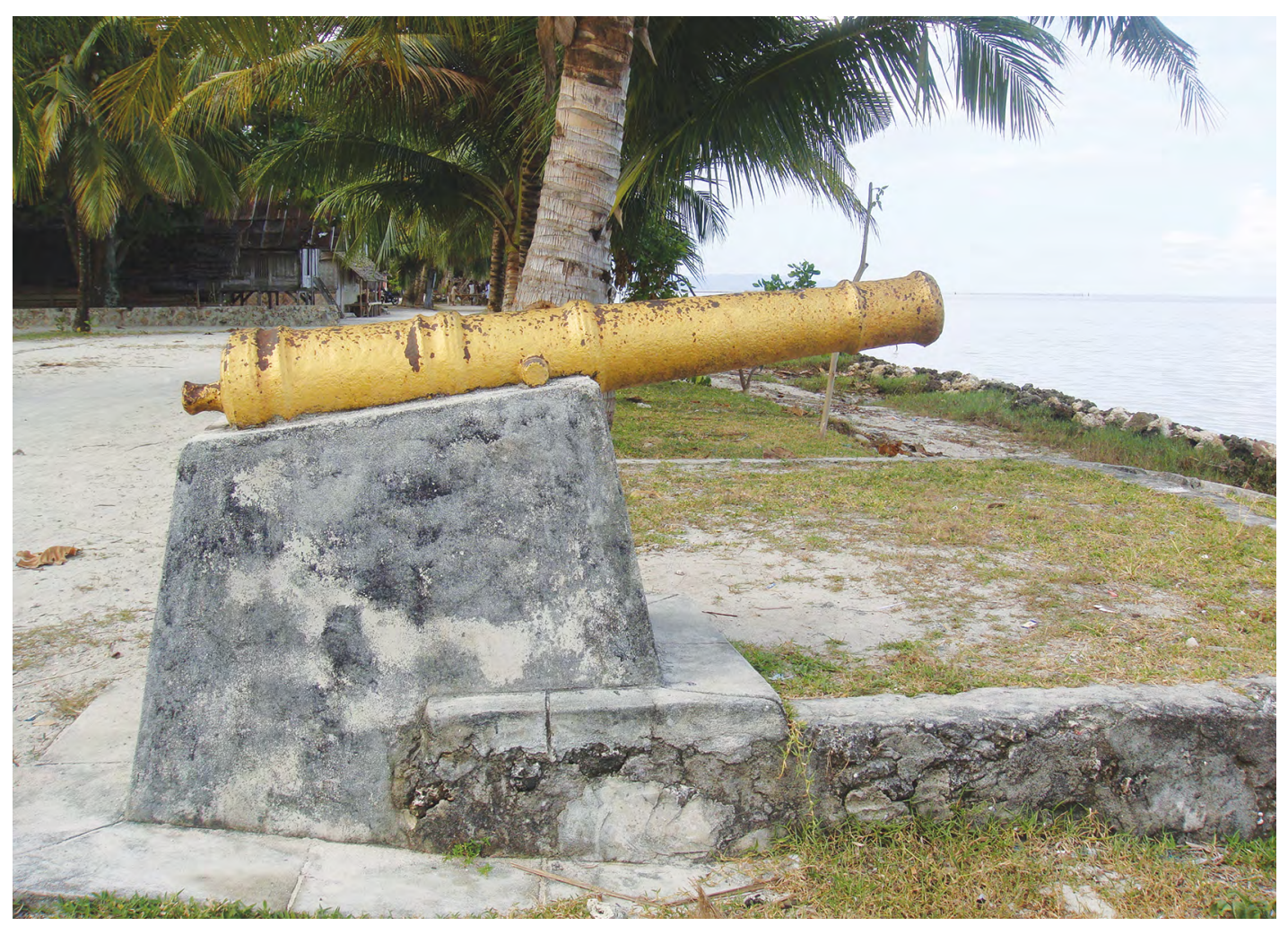

Figure 8.8. One of the ancient cannons in Fort Liwu now placed on the coast at Wabula.

Source: Photo courtesy of Hasanuddin.

An ancient cannon was once located inside the fort but has been moved to Wabula coastal village and placed near the village meeting house (Figure 8.8). In its shape and size, it resembles other cannons associated with Buton Sultanate forts. The Fort Liwu cannon is $116.5 \mathrm{~cm}$ long with the diameter on the front muzzle $7 \mathrm{~cm}$. It was welded together from six components, and has two reinforcing rings with a diameter of $5 \mathrm{~cm}$. The cascabel (subassembly of a muzzleloading cannon) is $2 \mathrm{~cm}$ long, and the breech in the ignition hole at the back of the cannon has a diameter of $3 \mathrm{~cm}$.

The plateau occupied by Fort Liwu is wide enough to accommodate residential areas. The structures inside the fort include ancient tombs (Figure 8.9), the former mosque and the ruins of houses. Although the surrounding land slopes steeply, it can be used to plant coconuts and other crops. Inside Fort Liwu, some fragments of foreign ceramics, particularly from China, were recovered. Plastic litter was found scattered around the settlement remains even though the site was abandoned in 1962, according to our informant, when the inhabitants were relocated to the lowlands to facilitate their administration. At the time of the survey, the fort surroundings were choked with reedy grass up to $1.6 \mathrm{~m}$, largely obscuring the ancient tombs and hindering the recovery of surface archaeological fragments. Nonetheless, the survey revealed enough of the fort structure for its plan to be sketched (Figure 8.10). 


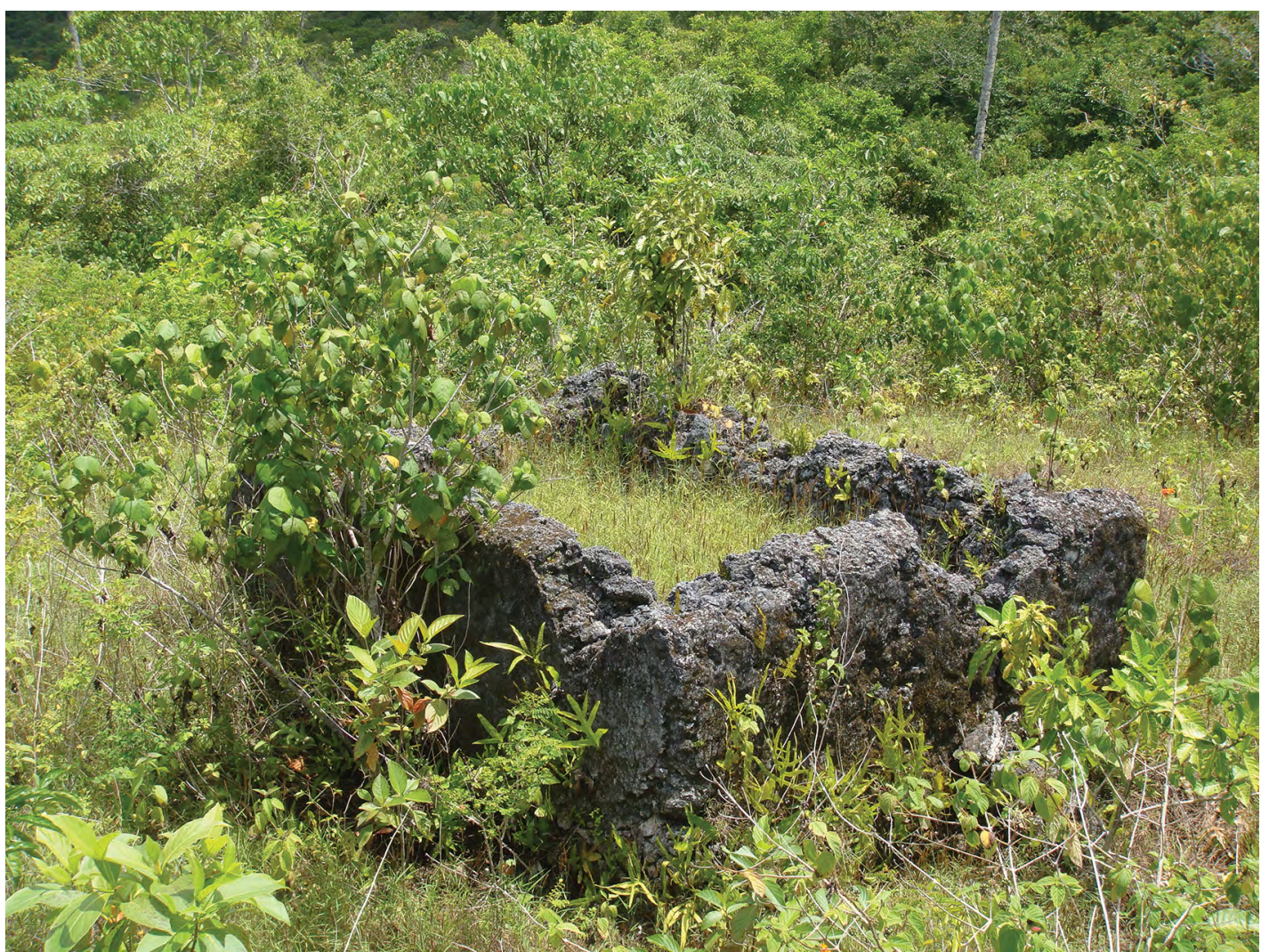

Figure 8.9. One of the ancient tombs inside Fort Liwu.

Source: Photo courtesy of Hasanuddin.

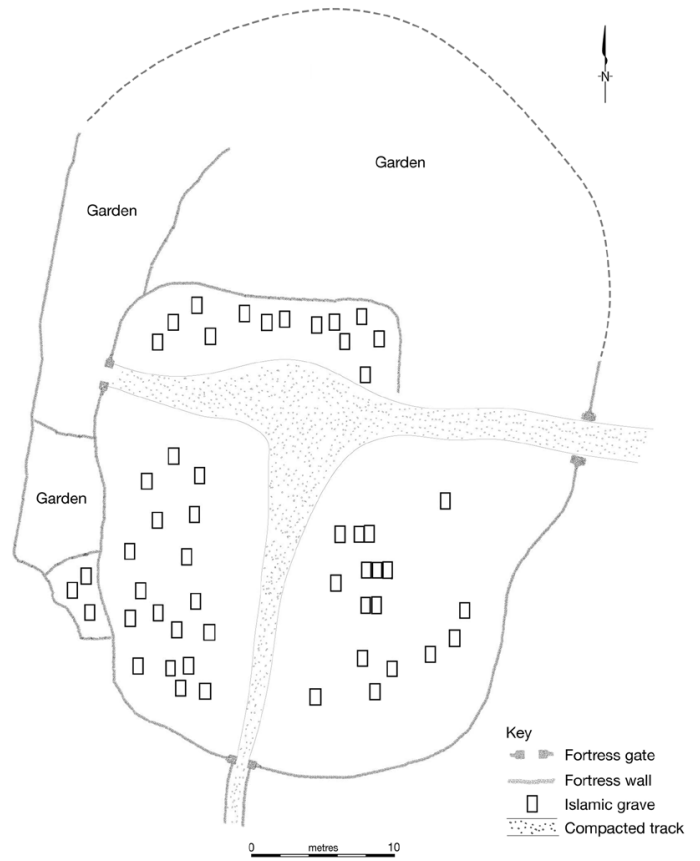

Figure 8.10. Plan of Fort Liwu in Wabula.

Source: Makassar Archaeology Office, redrawn by CartoGIS ANU.
An important structure of the fort is the wall at the centre of the fort, which used to be the mihrab of the fort's mosque (Figure 8.11). The other components of the mosque were relocated and rebuilt in Wabula village when Fort Liwu was abandoned. These heritage remains of the fort's small mosque are a visible reminder of Buton's history. They point to leadership of the community by the Buton ruler who had embraced Islam during his reign. 


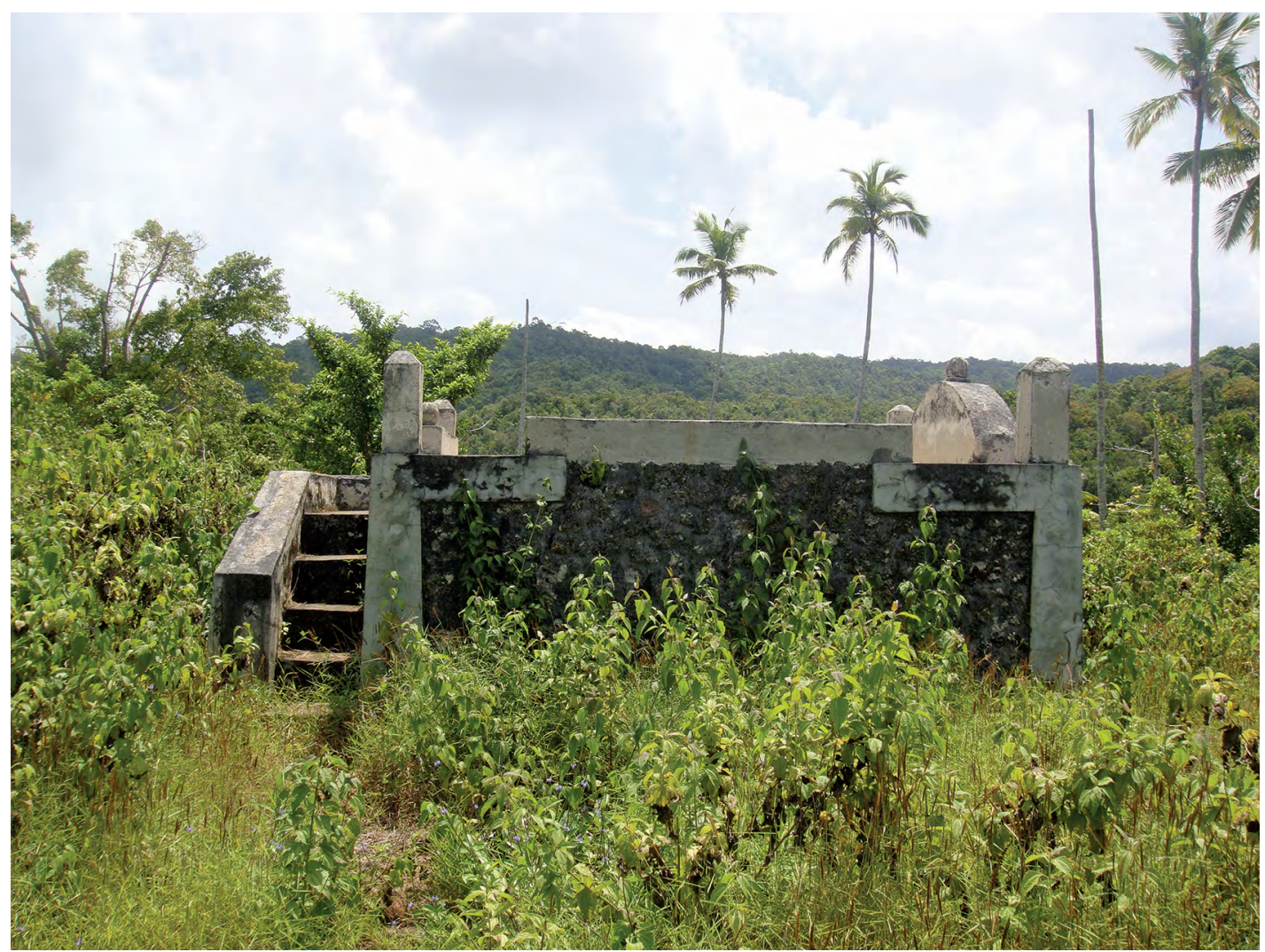

Figure 8.11. The former mihrab (a niche in the wall of a mosque) inside Fort Liwu, which also functioned as a tomb.

Source: Photo courtesy of Hasanuddin.

Valuable information is provided by Johannes Elbert's photographs, published in 1911, of Fort Liwu (which he called Fort Wabula). ${ }^{2}$ Elbert's photographs confirm the status of Benteng Liwu as a defensive fort and helped breathe life into its archaeological vestiges. One photograph shows one of the entrance gates to Benteng Liwu (Hasanuddin 2010: Foto 4). Above the gate is a guard post made of a thatched-roofed wooden construction with a bamboo ladder. The rooftop of the guard post is shaped like a pineapple. The same sort of guard post above the entrance gate can also be found in the Buton Palace at Bau-Bau. The pineapple symbol is strongly associated with the Buton Sultanate and features as a decorative carved emblem in contemporary designs of Buton architecture.

\section{Fort Kombeli}

Fort Kombeli, which is also commonly known as Fort Liwu, lies within the territory of Kombeli village, Pasar Wajo subdistrict. The coral rock walls, built to adjust to the sloping contour of the land, are around $1 \mathrm{~m}$ in height, but some parts are difficult to observe because the fort is split by a deep ravine. Three gates were located on the south, west and east sides. It is likely that there had been a gate along the north wall as commonly found in Buton forts, but our survey could not locate it as it was now ruined or buried underground. The south gate is $150 \mathrm{~cm}$ tall and $125 \mathrm{~cm}$ wide. The west gate (Figure 8.12) is $180 \mathrm{~cm}$ wide and $140 \mathrm{~cm}$ tall, flanked by walls around $110-140 \mathrm{~cm}$ thick.

2 Fort Wabula refers to the whole area to the top of the mountain encompassing the Fort Liwu site. 


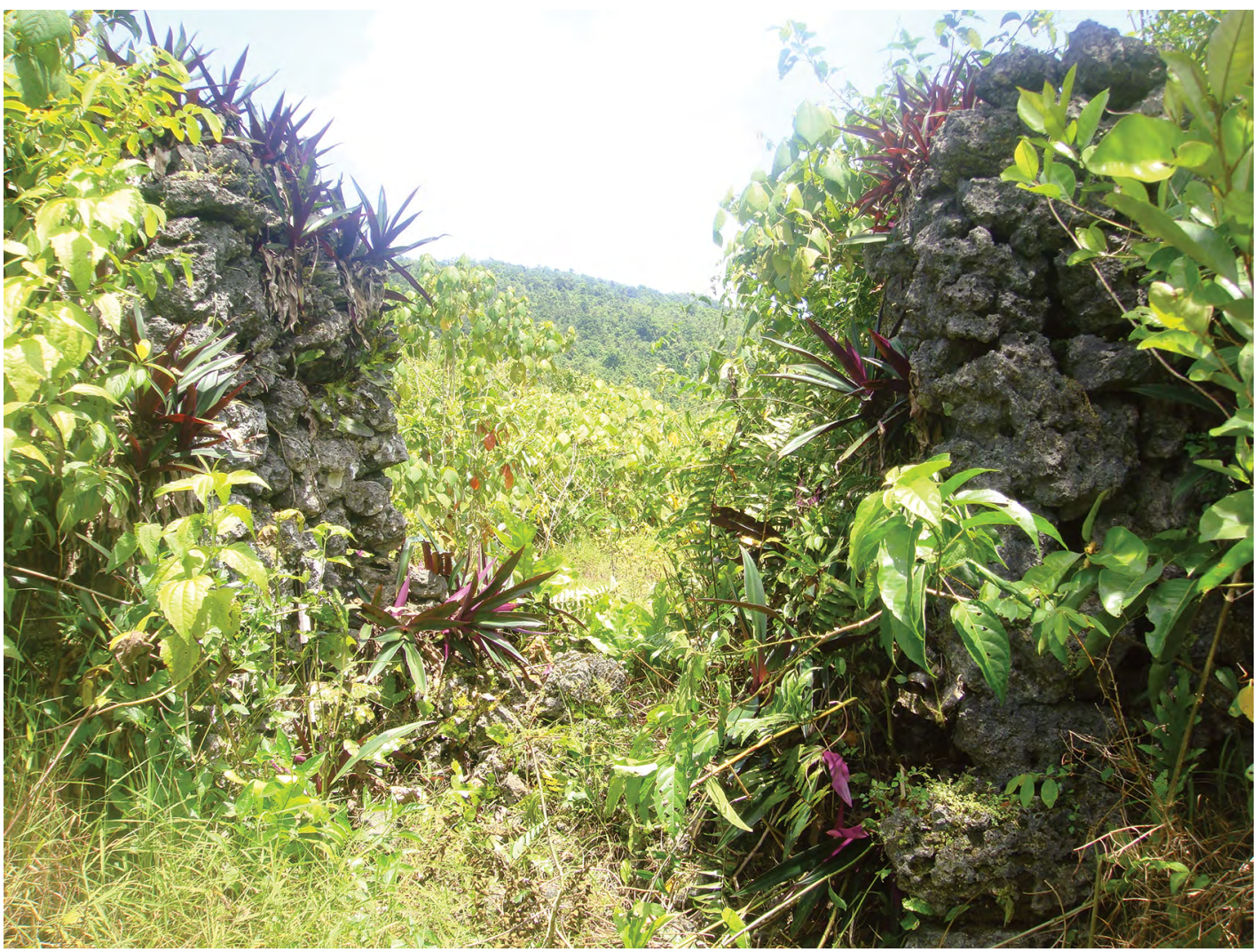

Figure 8.12. One of the gates into Fort Kombeli on the western side.

Source: Photo courtesy of Hasanuddin.

A great variety of tombs and tombstones are scattered across the interior of the fort, including the ancient tombs of the traditional leaders named the parabela. However, many of these tombs have been restored by the relatives of the deceased by building a cement wall around them (Figure 8.13). There is a rectangular-shaped tomb made of coral rock, which lacks a tombstone (Figure 8.14). The tombstone of another grave is shaped like a human head. This tombstone must have been made recently because, although made from coral rock, cement was used to help fashion the shape.

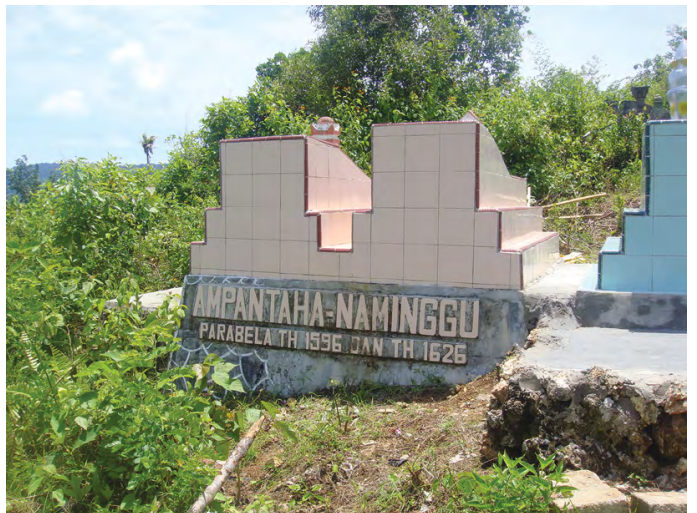

Figure 8.13. The restored tomb of one of the Parabela.

Source: Photo courtesy of Hasanuddin.

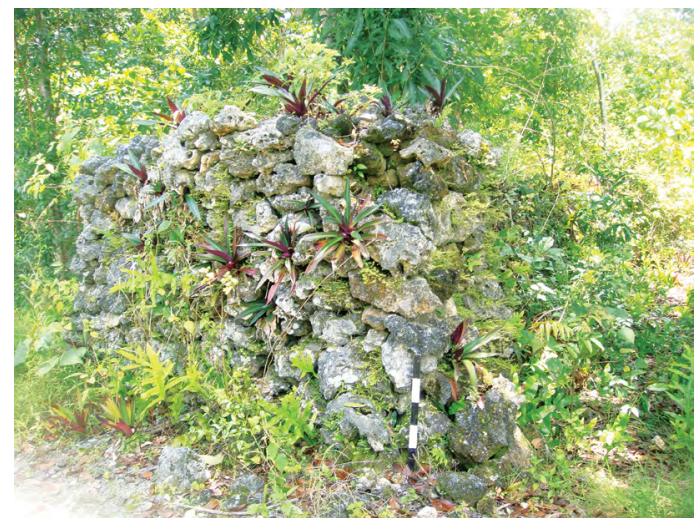

Figure 8.14. Fort Kombeli tomb made of coral rock.

Source: Photo courtesy of Hasanuddin. 


\section{Fort Takimpo}

Fort Takimpo, located in Takimpo village in Pasar Wajo subdistrict, was restored by the Southeast Sulawesi Provincial Government in 2006. It is ovoid in shape and the coral stone walls adjust to the land contours (Figure 8.15). The walls are $2 \mathrm{~m}$ tall and $1.5 \mathrm{~m}$ wide (Figure 8.16). The fort has five gates, a main gate located on the east (Figure 8.17), two gates along the west and a single gate to the south and the north. Each gate served as a bastion, with additional stone structures that included a guard post beneath and surveillance post on top. Each gate also has a roofed wooden building originally equipped with a pair of cannons, although none of these can be seen today.

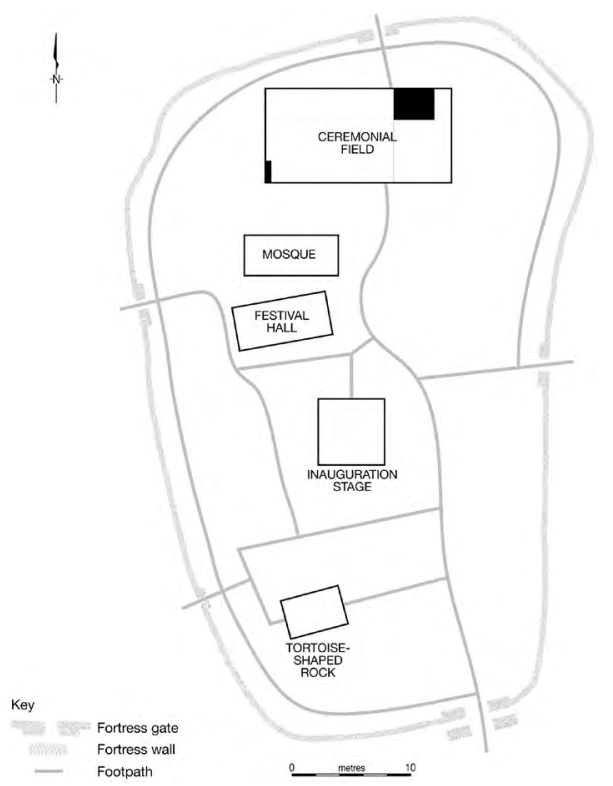

Figure 8.15. Plan of Fort Takimpo.

Source: Makassar Archaeology Office, redrawn by CartoGIS ANU.

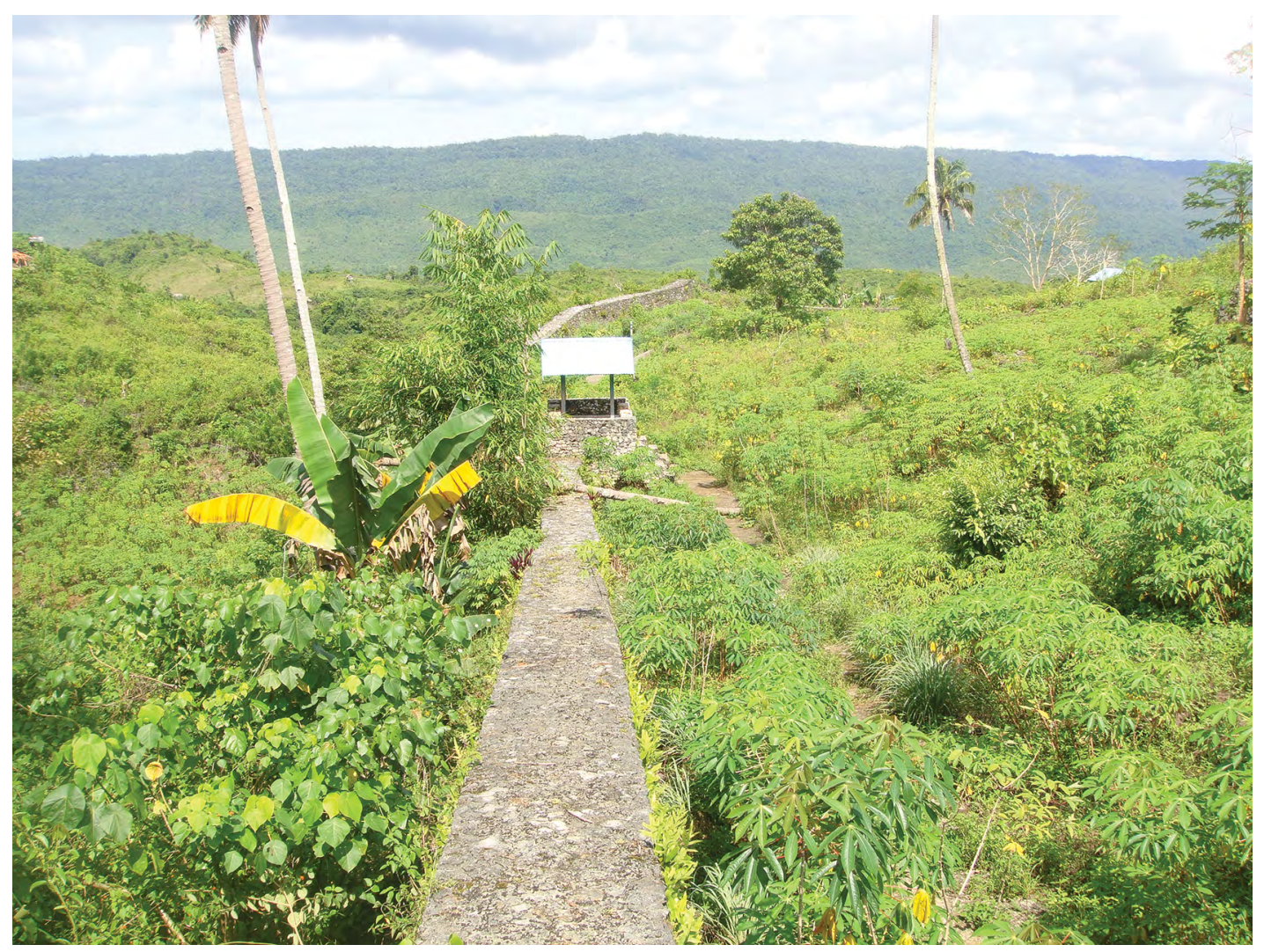

Figure 8.16. Fort Takimpo walls.

Source: Photo courtesy of Hasanuddin. 


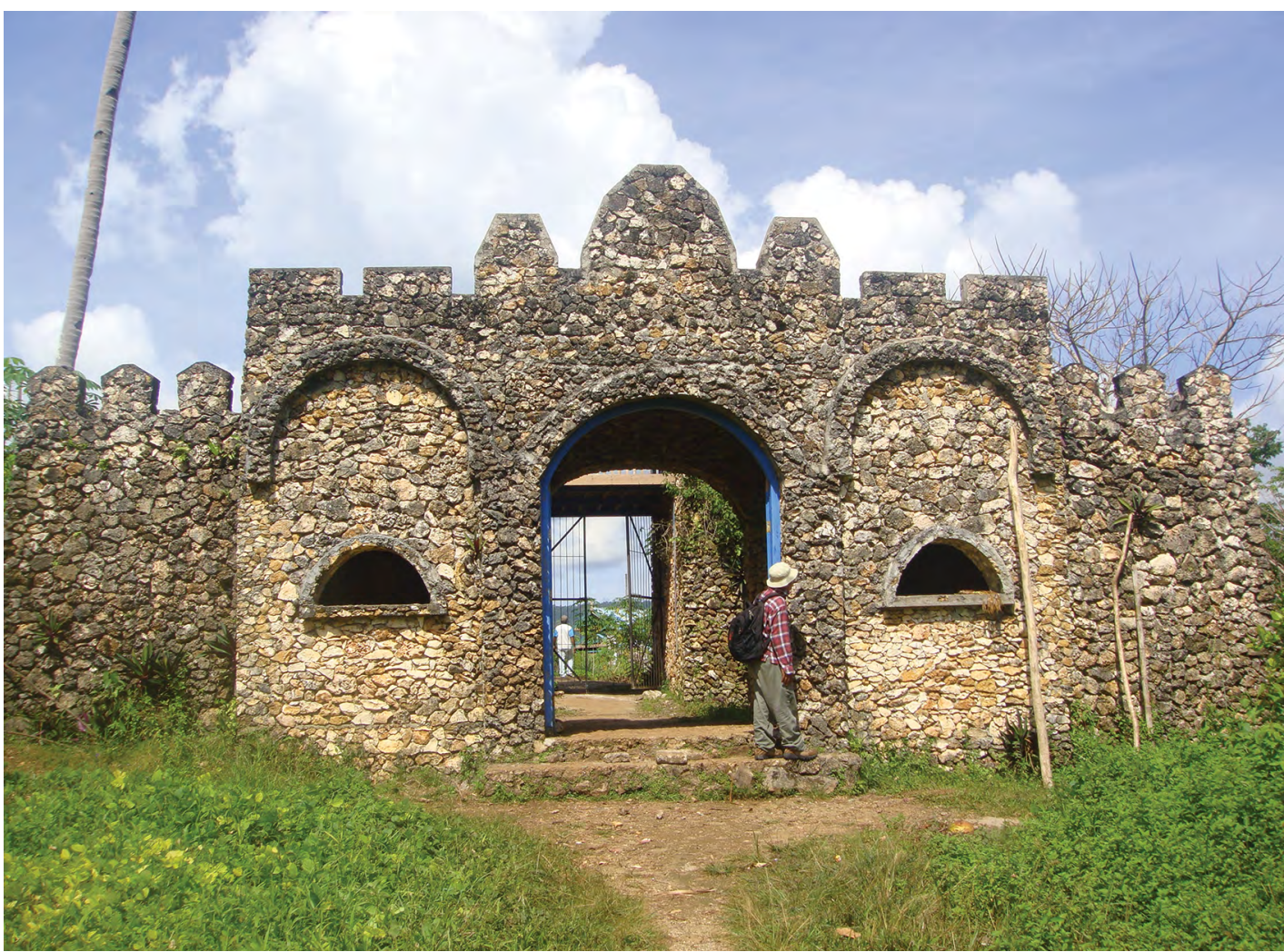

Figure 8.17. Main gateway into Fort Takimpo.

Source: Photo courtesy of Hasanuddin.

The fort allows a view over the surrounding topography, including the shoreline on the northern side, the hills and moderately shallow valleys on the east and southern sides, and a steep drop on the western side (which disappears from view). The surrounding hills were cultivated with seasonal crops.

The mosque, inauguration stone and ancient tombs inside the fort were restored by the Southeast Sulawesi Provincial Government in 2006. The mosque inside the fort is square in shape and has four main pillars (soko guru) directly supporting a multi-tiered roof structure. The western side has a niche extended outward from the wall called the mihrab, used by the imam to lead prayers (Figure 8.18). All these features are typical of ancient mosques in Indonesia.

At the top of the plateau near the mosque, there is a field that was formerly used as a place of ceremony. At that time, the royal flag was always raised there. To the east, there is an inauguration stage with coral rock structures shaped like chairs with back supports (Figure 8.19). According to the local people, the inauguration stage is still used to induct local leaders such as the parabela, moji and waci.

There is little information available on the historical function of the fort. According to local people, the fort was used to defend themselves against pirates and especially Tobelo raiders from Halmahera in neighbouring Maluku province, whom they feared most. The Tobelo reportedly often attacked the village to plunder their wealth and kidnap women and girls. 


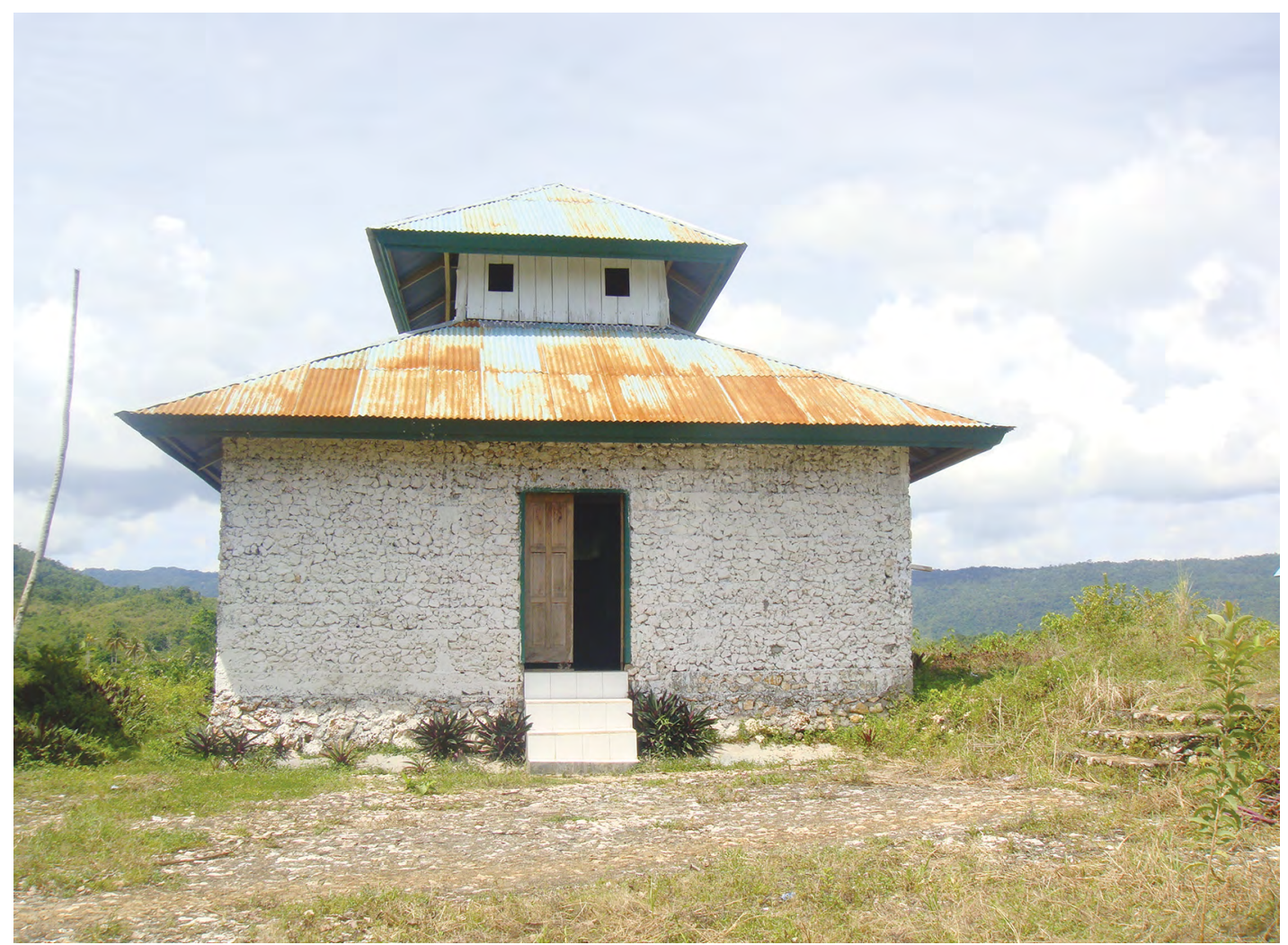

Figure 8.18. Mosque inside Fort Takimpo.

Source: Photo courtesy of Hasanuddin.

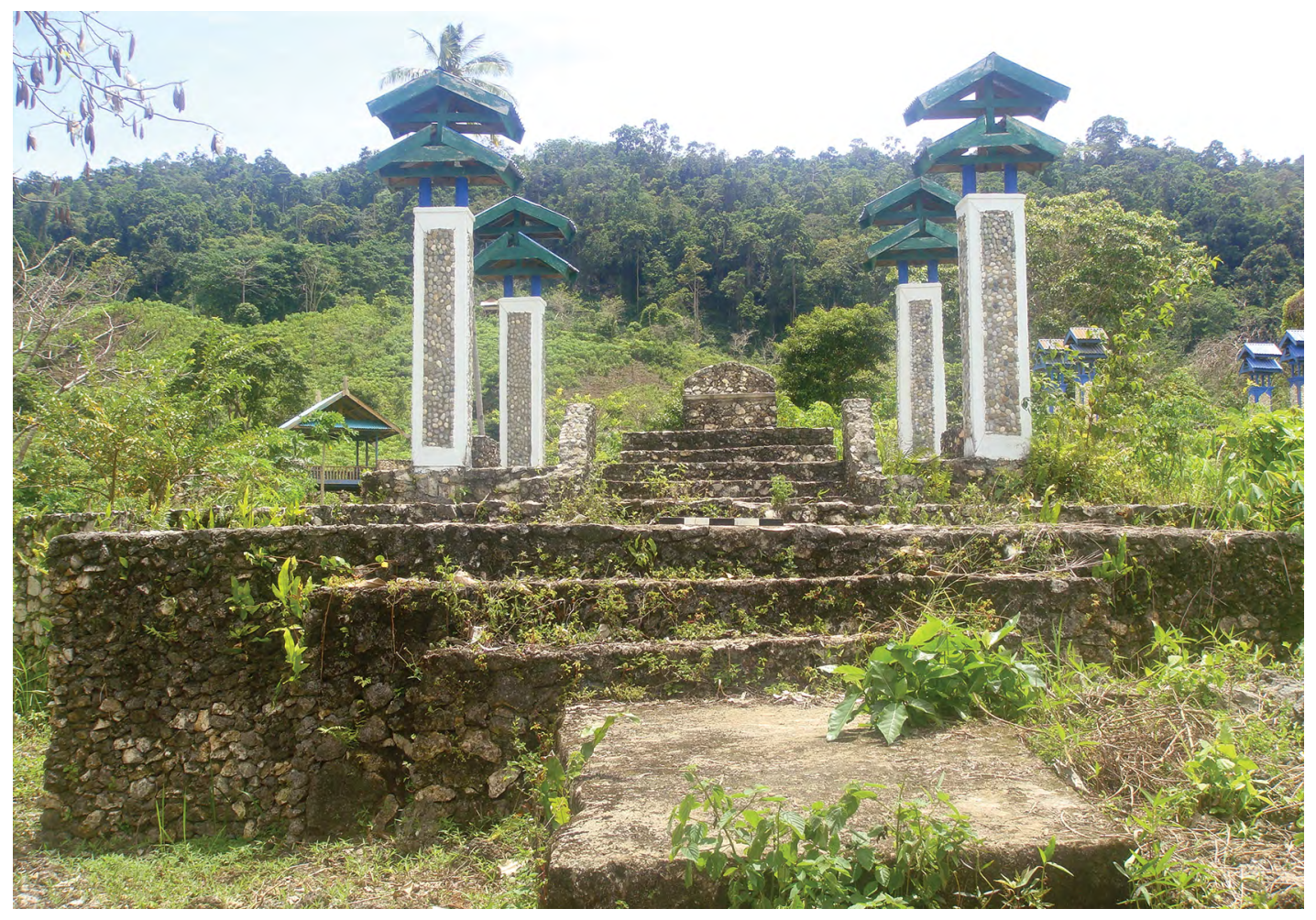

Figure 8.19. The inauguration stage in Fort Takimpo.

Source: Photo courtesy of Hasanuddin. 


\section{Discussion}

For populations without the technology to build defended settlements, sites difficult to access in the highlands would have offered a degree of security thanks to the natural protection of a deep river valley or steep cliffs. But as agriculture expanded, the lowlands would have offered the greatest opportunity for population increase due to the minimisation of time and energy costs in gathering life-supporting natural resources. Areas richest in natural resources would have become centres of social and cultural activity (Subroto 1983:1178). This would have included the establishment of rulership to coordinate adaptation to the abundant natural resources, expansion of food diversity, and distribution of human settlements to exploit the available resources. It also included defence, because the survival of society required a place of refuge during wartime as well as a centre of government. The Buton forts reflect not only the economic ability of the ruler, but also the presence of territorial forces to defend the people from external attack (Sarjiyanto 1999:99). Thus, we see that the defensive walls at Fort Koncu and Fort Liwu in Wabula enclose visible reminders of the former social order including ancient tombs, remnants of a palace, a place of agreement and a former mosque. In addition, the defensive purposes of the Buton forts were assisted by their position on locally elevated terrain.

In particular, the large number of fortifications in Buton can be understood in the context of the rising tensions between major maritime powers during the sixteenth and seventeenth centuries. During the late sixteenth century, Buton acknowledged Ternate as overlord and protector, but it fell prey to constant attack by Makassar with the turn of the century, followed by conquest in 1626. In 1667, Buton entered a treaty with the Dutch East India Company (Vereenigde Oostindische Compagnie, or VOC) during the prelude to the successful assault by the VOC on Makassar, after which Buton was returned to Ternate, which had also allied itself with the VOC (Andaya 1981, 1993). In addition to these large-scale conflicts, Buton also had to deal with tensions inside its insular domain, such as those presented by Tiworo Island with its strong presence of Samar 'sea gypsies' (Gaynor 2016). The perils of seaborne attack explain why the Liwu and Takimpo forts, as well as the Buton Palace, are notable for their elaborate defensive structures, such as bastions and their commanding view overlooking vital coastal landing sites. Forts like these make it difficult for an enemy to attack and break their lines of defence, which the enemy would have to do to seize land or control of a kingdom. These forts served as military defence posts, and displayed the concentration of power and control over the local economy in order to maintain the existence of the kingdom and its rulers.

The same strategy was followed by foreign powers when they pushed into the Indonesian Archipelago during the same era as the Buton forts proliferated. Initially the Portuguese, then the Dutch, English and Japanese maritime traders established networks of strategic fortified sites across the archipelago. These forts functioned not only as a shelter from belligerent local populations but also as a defence when the foreign powers went to war against each other over their competing economic interests. The forts were established as military and trading posts, their position determined by the imperative to control economic activities along river, land and sea routes. It is not surprising to find Dutch forts or Japanese bunkers established along the waterfront, a river delta or busy road travelled by traders and merchants.

Foreign colonial powers brought with them modern weaponry, and advanced fort construction technologies. A common characteristic of Portuguese and Dutch forts is a rectangular shape with bastions (rectangular or round in shape) at every corner to serve as monitoring posts-a feature emulated on the major Buton fortresses. The imperial powers also styled their forts according to the architecture of their home country, using bricks (such as Fort Banda built by the Portuguese in Maluku) or volcanic tuff stone plastered with cement and limestone (such as Fort Rotterdam 
in Makassar). Local adoption of introduced technology can be seen with the various brick forts built by Goa-Talloq in its defence of Makassar against the Dutch (see Chapter 7, this volume), and the use of brick in the Buton Palace and some other Buton forts.

\section{Conclusion}

The diverse social and cultural traditions of Buton Island indicate a pluralist and open society that welcomed external influences and sought to benefit from them while protecting its own interests. The Butonese, like the Bugis and Mandars, are renowned as seafaring people who traded widely and opened their minds to lifestyles in faraway places. In the process, they gathered a great diversity of trade goods and ideas to benefit social and cultural life in Buton. Evidence of this engagement can be seen in the relics and cultural heritage found to this day across Buton.

Archaeological surveys using an ethnohistorical approach have demonstrated the fortified status of the Koncu, Liwu, Kombeli and Takimpo forts on Buton Island. All four were built on elevated locations, and all of them except Kombeli on hilltops. The unelaborated coralline rock walls of Fort Koncu show that this site was a basic fortified residence, not a military defence post. Architecturally, Fort Liwu resembles Buton Palace in many aspects, including the shape of the entrance door, the two-layered walls, the bastion and the location of the former mosque.

After restoration by the Provincial Government of Southeast Sulawesi, Fort Takimpo and its building components can clearly be seen today. However, they still require ongoing maintenance and protection from the combined impacts of weathering and human agency.

Fort Koncu and Fort Kombeli lie in ruins, with their coral stone walls heavily degraded. If the forts are not restored promptly, the ruins will eventually disappear without a trace, leaving only a legend without physical verification. These forts are important relics of the multilayered defence system of the Buton kingdom that began as early as the fourteenth century AD, and as symbols of the greatness and power of the kingdom of Buton in the context of its cultural history. The Buton Culture and Tourism Office should coordinate with local households to discuss the management prospect of the forts or to develop Koncu and Kombeli into sites for cultural tourism. The forts on the Wakatobi Islands, which formed part of the defensive structure of the Buton Sultanate (Rosmawati 2018), are an example of the potential of these defensive structures for cultural tourism initiatives (Khiri Travel 2017). In the restoration effort, the rules of preservation must be followed, with emphasis on the authenticity of form and compliance with the available data, such as that collected through research by the Makassar Archaeology Office. Building components should not be added without drawing on evidence of pre-existing structural forms because such additions would mask the cultural significance of the forts.

\section{References}

Andaya, L.Y. 1981. The heritage of Arung Palakka: A history of South Sulawesi (Celebes) in the seventeenth century. Verhandelingen van het Koninklijk Instituut voor Taal-, Land- en Volkenkunde 91. Martinus Nijhoff, The Hague. doi.org/10.26530/oapen_613368.

Andaya, L.Y. 1993. The world of Maluku: Eastern Indonesia in the early modern period. University of Hawai'i Press, Honolulu.

Anonymous n.d. Local historical manuscript. Bau-Bau City Government Culture and Tourism Office, Bau-Bau. 
Baubau Post 2018. Tradis pindoko wapulaka, aset budaya busel yang hampir punah. Bau-Bau Post, baubaupost.com/2018/02/15/tradisi-pindoko-wapulaka-aset-budaya-busel-yang-hampir-punah/. Accessed 4 February 2020.

Bisht, N.S. and T.S. Bankoti 2005. Encyclopaedia of South-East Asian ethnography. Angus and Robertson, Sydney.

Colenbrander, H.T. 1919. Jan Pietersz. Coen: Bescheiden omtrent zijn Bedrijf in Indië. Part 1. Martinus Nijhoff, The Hague.

Elbert, J. 1911. Die wissenschaftlichen Ergebnisse der Sunda-Expedition des Frankfurter Vereins für Geographie und Statistik. Jean Roux, Frankfurt am Main.

Fadillah, M.A. and M.I. Mahmud 2000. Kerajaan siang kuna: Sumber tutur, teks dan tapak arkeologi. Balai Arkeologi Makassar, Makassar.

Gaynor, J.L. 2016. Intertidal history in Island Southeast Asia: Submerged genealogy and the legacy of coastal capture. Cornell University Press, Ithaca. doi.org/10.7591/9780877272304.

Gosden, C. 1994. Social being and time. Blackwell, Oxford.

Hasanuddin 2010. Eksistensi benteng Wabula sebagai bentuk pertahanan berlapis Kerajaan Buton Sulawesi Tenggara. Walennae 12(1):21-37.

Indonesia Tourism 2017. Southeast Sulawesi, Wakatobi. www.indonesia-tourism.com/south-east-sulawesi/ climate.html. Accessed 4 February 2020.

Kandari, A.M., S. Kasim, M.A. Limi and J. Karam 2015. Land suitability evaluation for plantation forest development based on multi-criteria approach. Agriculture, Forestry and Fisheries 4(5):228-238. doi.org/10.11648/j.aff.20150405.15.

Khiri Travel 2017. The magical Wakatobi Islands. khiri.com/discovery/the-magical-wakatobi-islands/. Accessed 4 February 2020.

Kompas Travel 2010. Pulau Makasar dan cerita masa lalu. Kompas.com travel.kompas.com/read/2010/ 03/13/15410668/Pulau.Makasar.dan.Cerita.Masa.Lalu. Accessed 24 March 2020.

Kumparan 2019. Kande kandea festival budaya buton yang jadi ajang mencari jodoh. kumparan.com/ kendarinesia.id/kande-kandea-festival-budaya-buton-yang-jadi-ajang-mencari-jodoh-1rHrPUBsEn9. Accessed 4 February 2020.

Nur, M. and R. Awat 2010. Menemukan kearifan lingkungan dalam pola pemukiman Keraton Buton. Walennae 12(1):53-64.

Purwanto, M.R. 2016. Acculturation amongst wisdom, law and Sufism in forming Martabat Tujuh Enactment of Buton Sultanate. International Journal of Humanities and Management Sciences 4(3):288-292. www.isaet.org/images/extraimages/EA0416024.pdf. Accessed 24 March 2020.

Reid, A. 1983. The rise of Makassar. Review of Indonesian and Malaysian Affairs 17:117-160.

Robson, S. (trans.) 1995. Desawarnana (Nagarakrtagama) by Mpu Prapanca. KITLV Press, Leiden.

Rosdin, A. 2014. Buton, Islamization and its manuscripts tradition. International Journal of Nusantara Islam 2(2):101-116. journal.uinsgd.ac.id/index.php/ijni/article/view/75. Accessed 24 March 2020. doi.org/10.15575/ijni.v2i2.75.

Rosmawati 2018. The roles of the Liya and Kaledupa forts at Wakatobi as defensive forts of the Buton Kingdom. In M.R. Abdul Wahab, R.M.A. Zakaria, M. Hadrawi and Z. Ramli (eds), Selected topics on archaeology, history and culture in the Malay world, pp. 55-72. Springer, Singapore. doi.org/10.1007/ 978-981-10-5669-7_5. 
Sarjiyanto 1999. Eksistensi kerajaan Buton: Kajian: benteng-benteng masa kesultanan. Walennae 3(1): 97-106.

Southon, M. 1995. The navel of the Perahu. Research School of Pacific and Asian Studies, The Australian National University, Canberra.

Subroto, P. 1983. Studi tentang pola pemukiman arkeologi kemungkinan-kemungkinan penerapannya di Indonesia. Pertemuan Ilmiah Arkeologi III, pp. 1176-86. Pusat Penelitian Arkeologi Nasional, Jakarta.

Wikipedia 2020. Buton. en.wikipedia.org/wiki/Buton. Accessed 4 February 2020. 
This text is taken from Forts and Fortification in Wallacea: Archaeological and Ethnohistoric Investigations, edited by Sue O'Connor, Andrew McWilliam and Sally Brockwell, published 2020 by ANU Press, The Australian National University, Canberra, Australia.

doi.org/10.22459/TA53.2020.08 